\title{
建物の取壊し理由とその存続期間等に関する研究 STUDY ON REASONS OF DEMOLITION AND LIFETIME OF BUILDINGS
}

\author{
飯田恭一*, 吉田倬 郎** \\ Kyouichi IIDA and Takuro YOSHIDA
}

\begin{abstract}
The purpose of this study is to clarify factors concerning the durability of buildings.
The processes of this study are :distributing questionnaires concerning demolished buildings to the members of JBMA ; comparing the factors of this survey with the factors of the former survey;analyzing the impact that the factors for demolished buildings affect the reasons of demolition.

The main results from this study are as follows.

1)The specific year that effective building age is more than 30 years and the number of completion is large, has the large number of demolished buildings.

2) Buildings are not torn down just because they are old. On the other hand, prominent stains of buildings will be a good reason for teardown.
\end{abstract}

Keywords: The reason of demolition, Deterioration and Obsolescence, Lifetime, The statutory useful life 取壊し理由，老朽化陳腐化，存続期間，法定耐用年数

\section{1. 研究背景と目的}

現在、建築の分野において、建設活動に伴う二酸化炭素の排出や 産業廃棄物の処理などが地球環境の悪化の観点から問題となってい る。日本における、建設分野が占める二酸化炭素排出量は産業連関 表を利用した推定では $43 \%{ }^{11}$ 、建設業が占める産業廃棄物排出量は 環境省の統計では $19 \% 2$ といずれも大きな割合を占めしており、そ の対策の一つとして建物の長寿命化が求められている。これにより、 建設活動に伴う二酸化炭素の排出を増加させず、建物の処分時にで る廃㶳物を減少させることができる。建物の長寿命化には、建物を 社会資産として認識し、修繕やメンテナンスを繰り返し行い使い続 けることが大切である。一方で、寿命を全うせずに取壊されている 建物は多数存在する。このような建物が存在する背景には、建物自 体の耐久性が低いということだけでなく、社会環境の変化に対する 建物の不適合化、建物の機能性低下等の様々な要因がある。これら の要因に大きく係わるのが「建物の耐用性」である。この「建物の 耐用性」は、耐用年数からも性能の評価ができ、資産価值の評価に も繫がるものである。耐用年数は、減価償却の際の基準となる法定 耐用年数とは基本的には違うものである。法定耐用年数は、最初の 不動産鑑定評価基準の減価修正の耐用年数を標準とする方法におい て、「一応の標準とし」と明記され、 5 年後の住宅宅地審議会答申で それが削除されたが 3) 、耐用年数と法定耐用年数の違いに対する理 解が欠けた議論が多いことも確かであるゅゅ。
本研究は、近年取壊された建物に関し、その存続期間等の建物概 要および取壊し理由について調查分析し、1991 年にも行った同様の 内容の「建物の取壊し理由に関する調查」結果 6) と比較し、社会情 勢や経済動向の変化および建築技術の進歩が建物の存続期間、取壊 し理由等に及ぼす影響を把握し、建物の耐用性に関わる要因の一端 を明らかにし、これらを踏まえ建物の長寿命かつ健全に使用される 建物に必要な要素を見出すともに建物の資産価值評価に繋がる知見 を得ることを目的としている。

\section{2. 調査対象と方法}

\section{2-1. 調查対象}

本研究の調查対象は、賃貸ビル業を営む企業であり、(社) 日本ビ ルヂング協会連合会および（財）日本不動産研究所の協力により調 查先を選定した。「建物の取壊し理由に関する調查」というアンケー 卜表を作成し、各企業を対象に回答を頂くという調查を行った。1991 年にも同様な調查（以下「前回調査」とする）を行っており、バブ ル期に当たる 1991 年調查とバブル崩壊後の回復期に当たる 2007 年 調查（以下「今回調查」とする）を比較することにより、建物の取 壊し理由における社会状況の差異の影響の解明を試みたものである。 主な調查先とした（社）日本ビルヂング協会連合会は、各地域協 会を会員とする連合会であるが、表 1 は、前回と今回調査について、 調查協力をお願いした地域協会と取壊し時期を示したものである。
*日本不動産研究所研究部 主幹

** 工学院大学建築学科 教授.工博
Expert Advisor, Japan Real Estate Institute

Prof., Dept. of Architecture, Kogakuin Univ. 
表 1 今回・前回調查の各地域ビルヂング協会と取壊し時期

\begin{tabular}{|c|c|c|c|}
\hline & 各地域協会と協会会員以外 & 送付件数 & 取壊し時期 \\
\hline $\begin{array}{l}\text { 2007年調査 } \\
\text { (2007年4月) }\end{array}$ & $\begin{array}{l}\text { 東京ビルヂング協会会員 } \\
\text { 埼玉ビルヂング協会会員 } \\
\text { 千葉ビルヂング協会会員 } \\
\text { 神奈川ビルヂング協会会員 } \\
\text { 名古屋ビルヂング協会会員 } \\
\text { 大阪ビルヂング協会会員 } \\
\text { ビルヂング協会会員以外 }\end{array}$ & $\left|\begin{array}{l}807 \text { 社 (回答は } \\
68 \text { 社95件) }\end{array}\right|$ & $\begin{array}{l}\text { 2004年1月～2006年 } \\
12 \text { 月 (3年間) }\end{array}$ \\
\hline $\begin{array}{l}\text { 1991年調査 } \\
\text { (1991年4月) }\end{array}$ & \begin{tabular}{|l|} 
東京ビルヂング協会会員 \\
ビルヂング協会会員以外 \\
\end{tabular} & \begin{tabular}{|l|}
540 社(回答は \\
121 社 165 件)
\end{tabular} & $\begin{array}{l}\text { 1986年1月～1990年 } \\
\text { 12月 (5年間) }\end{array}$ \\
\hline
\end{tabular}

\section{2-2. 調査票と調査分析の方法}

今回調査の調査票の内容は、表 2 のとおりで、前回調査との対比 を主眼としたことから同じ項目立てとしている。今回調查の回収し た調査票に関し、以下の分析を行った。

(1) 取壊し建物の概要等の単純集計を前回調査と比較した。

(2) 取壊し建物の過半近くを占めるオフィスビルの建設動向等と 取壊し建物の竣工年を比較した。

(3) 取壊し建物と新築建物の延床面積を前回調査と比較した。

(4) 取壊し理由(小項目レベル)に関し、をつけた回答を主要因と

し、○をつけた回答を付随的要因とし、それらの集計を前回調 査と比較した。

(5) 取壊し建物の概要等と取壊し理由の主要因 (大項目レベル)の 関係を前回調査と比較した。

(6) 存続期間の法定耐用年数比等と主要因との関係を分析し、法定 耐用年数への認識を確認した。

表 2 調査票の調查項目

1）取壊し建物について、竣エ年、取壊年月、所在地、構造、地上・地 下階、延床面積、主要用途、自社用・テナント用・共用、増改築歴

（2）取壊しを決める際に、増改築の検討の有無

(3) 取壊し後の状況

1) 取壊し後、同敷地に建物を建てたか

2) 新しく建てた建物について、竣工年、構造、地上・地下階、延床面積 主要用途、自社用・テナント用・共用

(4) 取壊し理由に該当する全てに○、そのなかで主なものに○をつける

ア. 自然災害を受けて建物が破損した チ. 建物内部のレイアウトが不便になった

イ、為災害を受けて建物が破損した

ウ. 建物の「使い道」がなくなった

工. 建物の所有権が移転した

オ. 敷地の権利が移転した

カ. 敷地が狭く増築が出来なかった

キ. 敷地の使用目的を変更した

ク. 都市再開発事業で建物を取壊した

ケ. 道路等整備事業で建物を取壊した

コ. 周りの環境が公害等により悪化した

サ. 立地条件の変化に対応させるため

シ. 敷地の法規制が変わり増床可能

ス. 建物の法規制が変わり対応が必要

セ.もともと設計に不備があった

ソももとも施工に不備があった

夕. 収容人員、収容物が増加し狭くなった

(5) 回答者が建物所有会社関係者、建物管理会社関係者か

表 2 の調查票 $(4)$ の取壊し理由として「マ.その他」の回答は、吟味 し 30 項目に振分け、「マ.老朽化」を新たに設けた。次に前回調查と 同様に取壊し理由の小項目を表 3 のとおり 9 つの大項目に分けた。

表 3 調查票(4)の取壊し理由の小項目と大項目の関係

\begin{tabular}{|c|c|c|c|}
\hline 大 項 目 & 小項 目 & 大 項 目 & 小 項目 \\
\hline 災害に関する理由 & ア.イ. & 設計施エに関する理由 & セ.ソ. \\
\hline 建物の存在自体に関する理由 & ウ.エ & 建物用途に関する理由 & タ.チ.ツ. \\
\hline 敷地に関する理由 & オ.カ. & 維持管理に関する理由 & $\bar{\tau}$. \\
\hline 社会環境の変化に関する理由 & $\begin{array}{l}\text { ク.ケ.コ } \\
\text { サ.シ.ス. }\end{array}$ & $\begin{array}{l}\text { 建物の老朽化陳腐化 } \\
\text { に関する理由 }\end{array}$ & $\begin{array}{l}\text { ト.ナ.ニ.ネ.ノ. } \\
\text { ハ.レ.フ.ホ.マ. }\end{array}$ \\
\hline
\end{tabular}

\section{3. 調査分析}

\section{$3-1$. 取壊し建物の概要等}

表 2 の調查票の $(1) \sim(3)$ の取壊し建物の概要等について、前回調査 と今回調査を比較した結果を表 4 に示す。

所在地は、東京都が前回調査と同じ $40 \%$ 台である。なお、今回調 查では前回調査と異なり、調查先として、名古屋・大阪ビルヂング 協会会員等が加わったため、中部・近畿地方が増加している。竣工

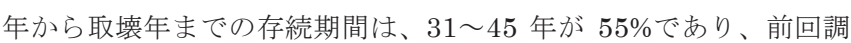
査では $21 〜 35$ 年が $56 \%$ であり、過半を占める山が 10 年長くなっ ている。階数は 9 階以上が $25 \%$ であ、前回調査の $4 \%$ とは、好対 照である。構造は、高層の建物が多いS R C 造が $31 \%$ あり、前回 調查では低層建物が多かったのでR C 造が $51 \%$ 、木造が $18 \%$ であ った。延床面積は、3001 $\mathrm{m}^{2}$ 以上が 43\%であり、一方前回調査では $1000 \mathrm{~m}^{2}$ 未満が $55 \%$ と小規模であった。用途は、調査先の関係から オフィス $58 \%$ 、店舗 $17 \%$ であり、前回調査に比べ多い。増改築歴は 有りが $42 \%$ で前回調査の $28 \%$ より増加しているが、地価高騰期の前 回調査と 1994 年以降の大不況期が係わる今回調査の違いが反映さ れている。取壊し時の増改築検討は有りが $39 \%$ 前回調査とほぼ同 じで慎重さが見受けられる。取壊し後の状況は、建築済・建築中・ 建築予定の合計が前回調查と同じ $70 \%$ 台で、建替え目的で取壊され ていることが伺える。

表 4 取壊し建物の概要等

\begin{tabular}{|c|c|c|c|c|c|c|c|c|c|c|}
\hline 所在地 & \multicolumn{2}{|c|}{$\begin{array}{l}\text { 都心三区(千代 } \\
\text { 田·中央·港区) }\end{array}$} & \multicolumn{2}{|c|}{$\begin{array}{l}\text { 東京都(都心 } \\
\text { 三区除く) }\end{array}$} & \multicolumn{2}{|c|}{$\begin{array}{l}\text { 首都圏(東 } \\
\text { 京都除く) }\end{array}$} & $\begin{array}{l}\text { 近畿 } \\
\text { 地方 }\end{array}$ & $\begin{array}{l}\text { 中部 } \\
\text { 地方 }\end{array}$ & その他 & $\begin{array}{l}\text { 有効 } \\
\text { 回答 }\end{array}$ \\
\hline 2007年 & \multicolumn{2}{|c|}{$20 \%$} & \multicolumn{2}{|c|}{$21 \%$} & \multicolumn{2}{|c|}{$19 \%$} & $18 \%$ & $14 \%$ & $8 \%$ & 89 \\
\hline 1991年 & \multicolumn{2}{|c|}{$24 \%$} & \multicolumn{2}{|c|}{$22 \%$} & \multicolumn{2}{|c|}{$24 \%$} & $1 \%$ & $1 \%$ & $28 \%$ & 164 \\
\hline 存続期間 & $\sim 15$ 年 & $\begin{array}{l}16 \sim \\
20 \text { 年 }\end{array}$ & $\begin{array}{l}21 \sim \\
25 \text { 年 }\end{array}$ & $\begin{array}{l}26 \sim \\
30 \text { 年 }\end{array}$ & $\begin{array}{l}31 \sim \\
35 \text { 年 }\end{array}$ & $\begin{array}{l}36 \sim \\
40 \text { 年 }\end{array}$ & $\begin{array}{l}41 \sim \\
45 \text { 年 }\end{array}$ & $\begin{array}{l}46 \sim \\
50 \text { 年 }\end{array}$ & 51年〜 & \\
\hline 2007年 & $5 \%$ & $4 \%$ & $3 \%$ & $11 \%$ & $22 \%$ & $12 \%$ & $21 \%$ & $10 \%$ & $12 \%$ & 81 \\
\hline 1991年 & $5 \%$ & $12 \%$ & $19 \%$ & $23 \%$ & $14 \%$ & $2 \%$ & $1 \%$ & $3 \%$ & $21 \%$ & 146 \\
\hline 地上階数 & 1階 & 2階 & 3階 & 4階 & 5階 & 6階 & 7階 & 8階 & 9階以上 & \\
\hline 2007年 & $7 \%$ & $13 \%$ & $14 \%$ & $9 \%$ & $14 \%$ & $5 \%$ & $5 \%$ & $8 \%$ & $25 \%$ & 85 \\
\hline 1991年 & $23 \%$ & $17 \%$ & $12 \%$ & $15 \%$ & $14 \%$ & $9 \%$ & $4 \%$ & $2 \%$ & $4 \%$ & 163 \\
\hline 構造 & \multicolumn{2}{|c|}{ RC造 } & \multicolumn{2}{|c|}{ S造 } & \multicolumn{2}{|c|}{ SRC造 } & \multicolumn{2}{|c|}{ 木造 } & その他 & \\
\hline 2007年 & \multirow{2}{*}{\multicolumn{2}{|c|}{$\begin{array}{l}42 \% \\
51 \%\end{array}$}} & \multicolumn{2}{|c|}{$18 \%$} & \multicolumn{2}{|c|}{$31 \%$} & \multicolumn{2}{|c|}{$6 \%$} & $3 \%$ & 83 \\
\hline 1991年 & & & \multicolumn{2}{|c|}{$12 \%$} & \multicolumn{2}{|c|}{\begin{tabular}{|l|}
$11 \%$ \\
\end{tabular}} & \multicolumn{2}{|c|}{$18 \%$} & $8 \%$ & 158 \\
\hline 延床面積 & \multicolumn{2}{|c|}{$\sim 1000 \mathrm{~m}^{2}$} & \multicolumn{2}{|c|}{$\begin{array}{l}1001 \sim 2000 \\
\mathrm{~m}^{2}\end{array}$} & \multicolumn{2}{|c|}{$\begin{array}{l}2001 \sim 3000 \\
\mathrm{~m}^{2}\end{array}$} & \multicolumn{2}{|c|}{$\begin{array}{l}3001 \sim \\
10000 \mathrm{~m}^{2}\end{array}$} & $\begin{array}{l}10000 \mathrm{~m}^{2} \\
\sim\end{array}$ & \\
\hline 2007年 & \multicolumn{2}{|c|}{$33 \%$} & \multicolumn{2}{|c|}{$12 \%$} & \multicolumn{2}{|c|}{$12 \%$} & \multicolumn{2}{|c|}{$23 \%$} & $20 \%$ & 85 \\
\hline 1991年 & 5 & & 2 & & & \%\% & & $\%$ & $4 \%$ & 161 \\
\hline 用途 & オフ & イス & 店 & 舗 & 社員暑 & 社宅 & 鉄道 & 施設 & その他 & \\
\hline 2007年 & 5 & & & $\%$ & & $\%$ & & $\%$ & $15 \%$ & 89 \\
\hline 1991年 & 4 & & & $\%$ & & $\%$ & & $7 \%$ & $24 \%$ & 161 \\
\hline 利用形態 & 自神 & 土用 & テナ & ント用 & & 用 & & & & \\
\hline 2007年 & 3 & & 5 & $\%$ & & $5 \%$ & & & & 86 \\
\hline 1991年 & 7 & & & $\%$ & & $\%$ & & & & 157 \\
\hline 増改築歴 & & 有り & & & 無し & & & & & \\
\hline 2007年 & & $42 \%$ & & & $58 \%$ & & & & & 85 \\
\hline 1991年 & & $28 \%$ & & & $72 \%$ & & & & & 157 \\
\hline \begin{tabular}{|l|} 
取壊し時 \\
の検討
\end{tabular} & 増改築 & の検討 & 有り & 増改等 & 菼の検言 & 寸無し & & & & \\
\hline 2007年 & & $39 \%$ & & & $61 \%$ & & & & & 85 \\
\hline 1991年 & & $40 \%$ & & & $60 \%$ & & & & & 159 \\
\hline $\begin{array}{l}\text { 取壊し後 } \\
\text { の状況 }\end{array}$ & 建 & Cた & 建て & ている & 建て & 可予定 & 建て & ない & 未定 & \\
\hline 2007年 & 2 & & 2 & $\%$ & & $3 \%$ & & $5 \%$ & $12 \%$ & 86 \\
\hline $\begin{array}{l}1991 \text { 年 } \\
\end{array}$ & $\frac{2}{4}$ & & $\frac{2}{2}$ & $\%$ & & $\%$ & & $9 \%$ & $5 \%$ & 165 \\
\hline
\end{tabular}

\section{3-2. 取壊し建物の竣エ年とオフィスビル建設動向の比較}

取壊し建物の用途はオフィスビルが多いことから、取壊し建物 の䇋工年とオフィスビル建設動向を比較する。オフィスビル建設 動向については、（財）日本不動産研究所全国オフィスビル調查 ${ }^{12}$ 
の全都市の年次別オフィスビル建設動向（以下「ビル建設動向」と する）によるものとする。ビル建設動向は、建築用途が主に事務所 である建物を対象とし、三大都市は延床面積 $5,000 \mathrm{~m}^{2}$ 以上、主要都 市は $3,000 \mathrm{~m}^{2}$ 以上を対象規模とし、中小規模の事務所ビルは除かれ ている。参考として市街地価格指数(六大都市商業地) 13 を掲載する。 ビル建設動向(図 1)では、東京オリンピック開催から 2 年後の 1966 年の山、列島改造ブームから 2 年後の 1974 年の山、市街地価 格指数が示寸地価高騰期から 2 年後の 1994 年の山、東京区部の床 面積が 300 万 $\mathrm{m}^{2}$ を超えた所謂 2003 年問題の山が見られる。

取壊し建物の竣工年(図 2) は、前回調査では存続期間が $21 \sim 30$ 年 となる竣工年 1961〜1965 年に山がきているが、この山は今回調査 でも見られ、ビル建設動向の 1966 年の山とほぼ対応する。今回調 查では、存続期間 30 年以上である 1971〜1975 年の次の山が出現 し、この山はビル建設動向の 1974 年の山と対応する。

以上から、今回調查では建物の取壊し時期は、ビル竣工が多い年 次で且つ存続期間 30 年以降の竣工年 $1961 \sim 1965$ 年と $1971 \sim 1975$ 年に、一方、地価高騰期の前回調査では、ビル竣工が多い年次で且 つ存続期間 $21 \sim 30$ 年の竣工年 1961〜 1965 年に山がきていること が分かる。

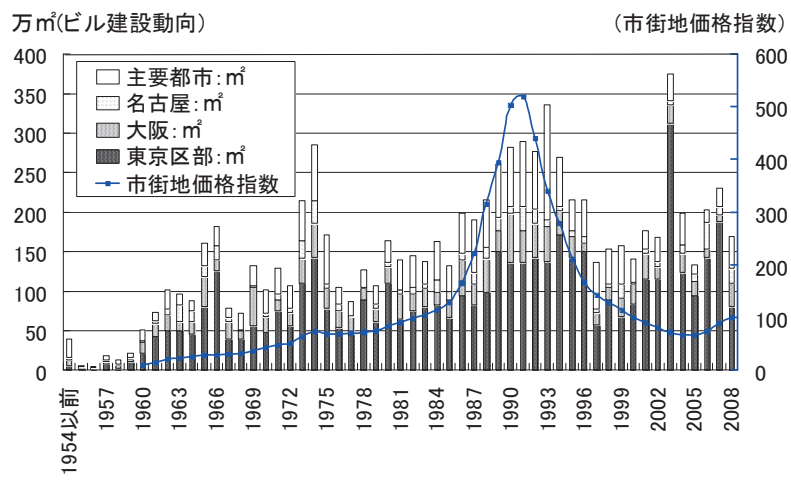

図 1 ビル建設動向と市街地価格指数の年次推移
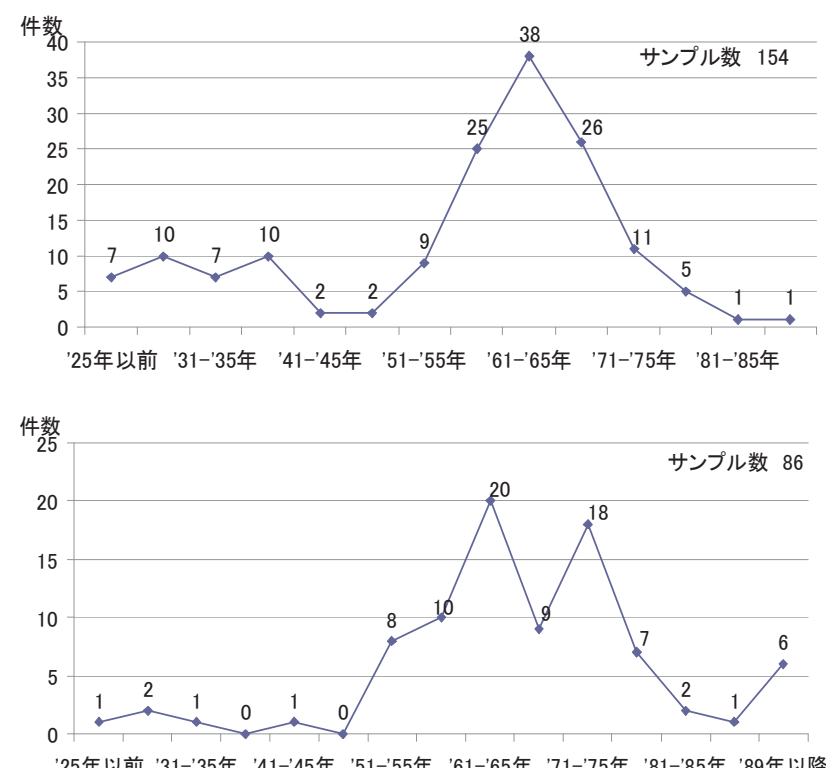

図 2 取壊し建物の竣工年（上 1991 年 下 2007 年）

\section{3-3. 取壊し建物と新築建物の延床面積の比較}

取壊し建物(以下「旧建物」とする) と同敷地に新築した又は新築 中の建物(以下「新建物」とする)の延床面積の比較について、前回 調查と今回調查の結果を図 $3 \cdot 4$ 亿示す。

新旧建物の延床面積変化を面積区分で見ると、図 3 のとおりであ る。今回調查では、旧建物 $2000 \mathrm{~m}^{2}$ 未満の区分のものが新建物も 2000 $\mathrm{m}^{2}$ 未満の同一区分が殆どであり、また旧建物 $14000 \mathrm{~m}^{2}$ 以上の 11 件 のうち 8 件が $20000 \mathrm{~m}^{2}$ 以上であり新建物も $20000 \mathrm{~m}^{2}$ 以上である。 前回調査では旧建物 $2000 \mathrm{~m}^{2}$ 未満の区分は、新建物も $2000 \mathrm{~m}^{2}$ 未満が 過半であるが、旧建物 $2000 \mathrm{~m}^{2}$ 以上の大半は新建物の面積区分が上 位の区分となっている。

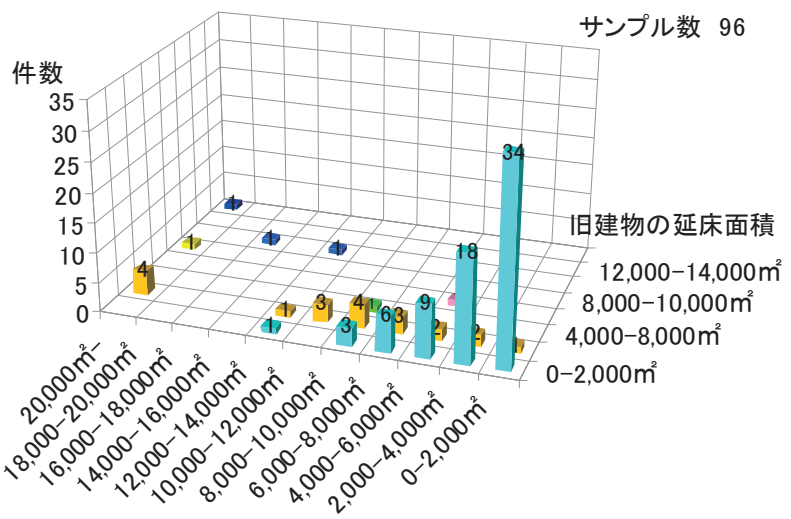

新建物の延床面積

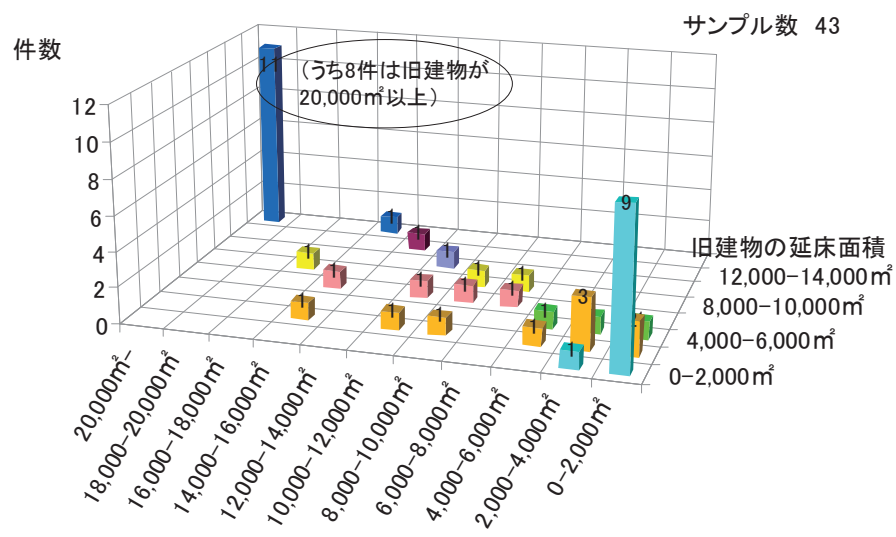

新建物の延床面皘

図 3 新旧建物の延床面積（上 1991 年 下 2007 年）

次に、新旧建物の延床面積の変化を、新建物の延床面積が旧建物 から増加した面積区分に含まれる件数で見ると、図 4 のとおりであ る。今回調查は、新建物の延床面積が $5000 \mathrm{~m}^{2}$ 以上増加した区分に 含まれるものが $40 \%$ であが、一方、前回調査は、 $24 \%$ に留まって いる。

今回調査において取壊し建物の用途がオフィスに関し、新旧の延 床面積が判明している 23 件の面積変化は、表 5 のとおりである。 即ち約 $1 / 3$ が 1 割未満の増加ないし減少であり、建替えが容積ア ップを目指す動機ばかりではないことが同われ、その一方、20000 $\mathrm{m}^{2}$ 以上を超える大規模建物は、建替え後には大幅な容積アップを示 している。 


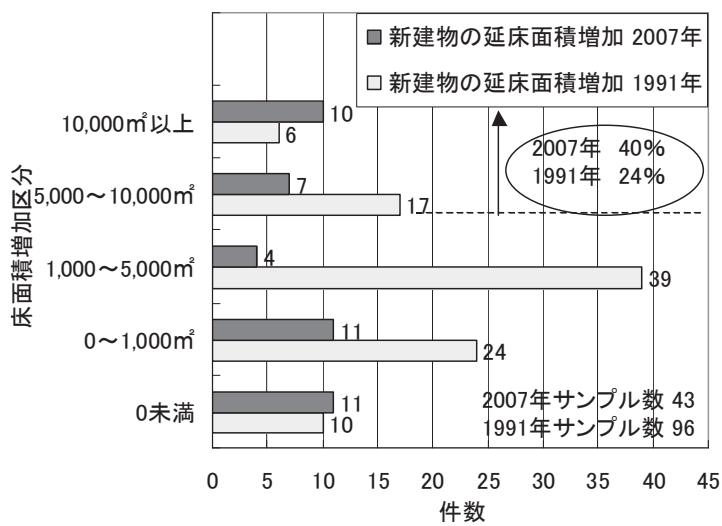

図 4 新建物の延床面積の増加区分

表 5 取壊し建物の用途がオフィスの新旧延床面積比較 (2007年)

\begin{tabular}{|c|c|c|c|c|c|}
\hline \begin{tabular}{|l} 
A 取壊し建物 \\
延床面積 $\left(\mathrm{m}^{2}\right)$
\end{tabular} & $\begin{array}{l}\text { B 建替え建物 } \\
\text { 延床面積 }\left(\mathrm{m}^{2}\right)\end{array}$ & $B / A$ & $\begin{array}{l}\text { A 取壊し建物 } \\
\text { 延床面積 }\left(\mathrm{m}^{2}\right)\end{array}$ & \begin{tabular}{||l|} 
B 建替え建物 \\
延床面積 $\left(\mathrm{m}^{2}\right)$
\end{tabular} & $B / A$ \\
\hline 2969 & 1751 & 0.59 & $\begin{array}{r}51637 \\
\end{array}$ & $* 84489$ & 1.64 \\
\hline 4320 & 3520 & 0.81 & 18379 & $* 30072$ & 1.64 \\
\hline 3776 & 3168 & 0.84 & 55274 & $* 90440$ & 1.64 \\
\hline 3515 & 3408 & 0.97 & 900 & 1600 & 1.78 \\
\hline 9073 & 8991 & 0.99 & 24320 & 45629 & 1.88 \\
\hline 8000 & 8180 & 1.02 & 6184 & 11640 & 1.88 \\
\hline 3700 & 3856 & 1.04 & 266 & 561 & 2.11 \\
\hline 6247 & 6715 & 1.07 & 36800 & 79500 & 2.16 \\
\hline 12416 & 14000 & 1.13 & 68180 & 150000 & 2.20 \\
\hline 14410 & 16576 & 1.15 & 65488 & 195000 & 2.98 \\
\hline 1060 & 1480 & 1.40 & 2840 & 11070 & 3.90 \\
\hline 16092 & 24058 & 1.50 & & & \\
\hline
\end{tabular}

*は、一団の計画であるので、建替え後の延床面積を3棟の建替え前の延床面 積割合で按分した。

(サンプル数 23)

\section{3-4. 取壊し理由の主要因集計と付随的要因集計}

調査票の $(4) の$ 取壊し理由 (以下「小項目」とする)の主要因集計と 付随的要因集計について、前回調査と今回調查の結果を図 5 に示す。

主要因、付随的要因を合計した全体集計が、今回調査で多かった 項目について、前回調査と比較すると、前回調查で相対的には多く なかった「建物の使い道がなくなった」「維持管理費用が増加した」、 「地震・強風に耐えられなくなった」が相対的に多くなった。逆に、 前回調査で多かった「建物の壁や柱などにひび割れが目立つように なった」、「収容人員、収容物が増加し、狭くなった」、「建物の内部 のレイアウトが不便になった」が今回調查で少なくなった。

主要因の集計が、今回調査で多かった項目について、前回調査と 比較すると、前回調查で多かった「建物の使い道がなくなった」が 最も多くなり、前回調查で多かった「敷地の使用目的を変更した」 と前回調査で少なかった「地震・強風に耐えられなくなった」も相 対的に多かった。逆に前回調査で最も多かった「立地条件の変化に 対応させるため」が少なくなり、多かった「収容人員、収容物が増 加し、狭くなった」が今回調査では無かった。

同様に、付随的要因ついて前回調査と比較すると、今回調査も「建 物の污れが目立つようになった」が最も多く、建物取壊しの有力な きっかけであることが推察できる。また、前回調查で多かった「維 持管理費用が増加した」、「設備の故障が多くなった」が今回調査で も相対的に多かった。逆に前回調査で多かった「建物の壁や柱など にひび割れが目立つようになった」「建物のデザインを一新する必要 が生じた」が今回調査では少なくなった。

今回調査で「建物の使い道がなくなった」と「維持管理費用が増 加した」が多くなったが、前者は不動産の有効利用意識の強まりが
見られ、後者は不動産運用上の支出項目であり、効率性の重視の影 響が見られる。一方、今回調査で「立地条件の変化に対応させるた め」と「建物の壁や柱などにひび割れが目立つようになった」が少 なくなったが、前者は積極的な投資姿勢の後退が影響したものと、 後者は 1995 年の耐震促進法の施行及び 2005 年の改正法成立が影響 して一部が「地震・強風にたえられなくなった」(「而震性」という 具体的な状況を記載した「その他」の項目も含む）という項目に移 動したものと推察する。また、今回調査で少なくなった「収容人員、 収容物が増加し、狭くなった」、「建物の内部のレイアウトが不便に なったから」は、どちらかと言えば自社用ビル特有の理由であり、 今回調査では、テナント用が多いことから少なくなったと推察する。

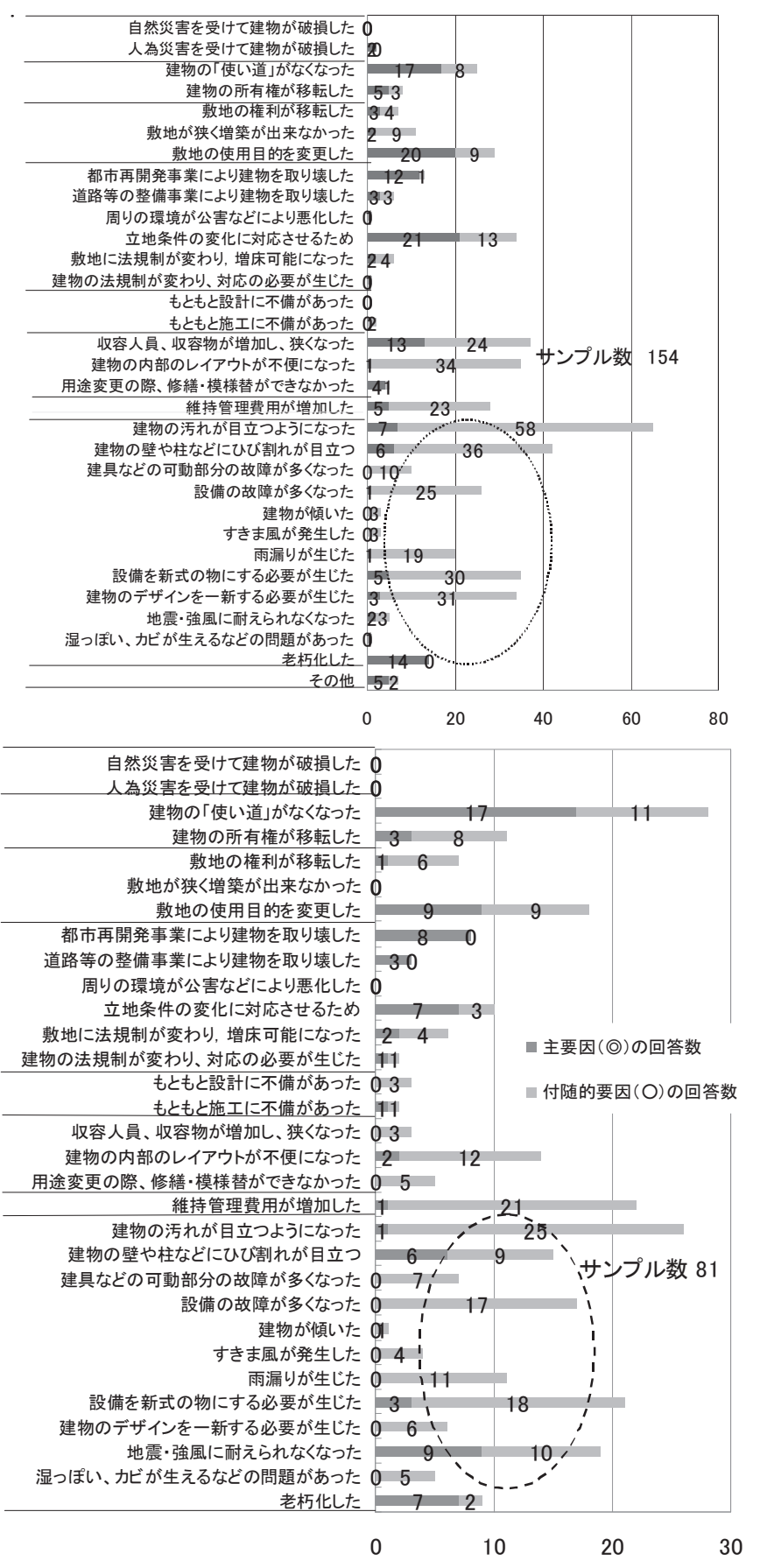

図 5 取壊し理由の小項目集計（上 1991 年下 2007 年） 


\section{3-5. 取壊し理由の主要因 (大項目) と建物の概要等との関係}

取壊し理由の大項目について、前回・今回調査の主要因の状況は 表 6 のとおりである。今回調査では、主要因は「建物の老朽化陳腐 化に関する理由」、「社会環境の変化に関する理由」、「建物の存在自 体に関する理由」の順で、この 3 つで大半を占め、前回調查では多 く見られた「敷地に関する理由」、「建物用途に関する理由」が、今 回は少なくなった。この変化は、今回調查は利用形態がテナント用 であるものが多いことも影響しているものと考えられる。

表 6 取壊し理由の主要因の状況および主要因における老朽化陳 腐化が付随的要因として示されている状況

\begin{tabular}{|c|c|c|}
\hline 大項目（主要因） & $\begin{array}{c}\text { 2007年調查 } \\
\text { 付随要因/主要因 }\end{array}$ & $\begin{array}{c}\text { 1991年調査 } \\
\text { 付随要因/主要因 }\end{array}$ \\
\hline 1.災害に関する理由 & 0 & $0 / 2$ \\
\hline 2. 建物の存在自体に関する理由 & $12 / 20$ & $6 / 22$ \\
\hline 3. 敷地に関する理由 & $4 / 10$ & $12 / 25$ \\
\hline 4. 社会環境の変花に関する理由 & $10 / 21$ & $15 / 33$ \\
\hline 5. 設計·施エに関する理由 & $1 / 1$ & 0 \\
\hline 6. 建物用途に関する理由 & $2 / 2$ & $8 / 18$ \\
\hline 7. 維持管理に関する理由 & $1 / 1$ & $5 / 5$ \\
\hline 8. 建物の老朽化陳腐化に関する理 & $13 / 26$ & $-/ 39$ \\
\hline 9. その他の理由 & 0 & $7 / 15$ \\
\hline サンブル数 & 81 & 154 \\
\hline
\end{tabular}

次に、建物諸元について各区分における、前回・今回調査の取壊 し理由の主要因(大項目)として最も多く示されたものの状況は、表 7 のとおりである。

所在地別の状況は、都心三区では前回調查と同じく「社会環境の 変化」が最も多く、首都圈（都心三区を除く）では前回調查は「老 朽化陳腐化」が、今回調查は「建物の存在自体」が最も多い。存続 期間の状況は、最頻 31〜 40 年は設備の更新等の検討時期であり「老 朽化陳腐化」が最も多くを占め、逆に、20 年未満の短い建物と 51 年以上の長い建物は「社会環境の変化」が最も多い。一方、前回調 查では、存続期間の最頻 21 30 年は「社会環境の変化」が最も多 い。構造別の状況は、 $\mathrm{RC}$ 造では前回調查が「社会環境の変化」で 今回調查が「建物の存在自体」が最も多い。延床面積別の状況は、 表 4 に示寸とおり前回調查最頻の $1000 \mathrm{~m}^{2}$ 未満も今回調查最頻の $3000 \mathrm{~m}^{2}$ 以上も、「社会環境の変化」が最も多い。用途の状況は、才 フィスでは前回調査が「社会環境の変化」で今回調査が「老朽化陳 腐化」が最も多い。前回調查は、図 1 に示寸地価が高騰した時期で あり、「社会環境の変化」への対応を促し、ビル竣工の多さに反映し ている様子が伺われた。一方、今回調查の「老朽化陳腐化」の詳細 は、図 5 に示す「壁等にひび割れが目立つ」、地震等に耐えられな かった」、老朽化」が大半であることから、リニューアルを検討の うえ取壊していることが伺える。主たる用途がオフィスで店舗併用 では、前回・今回調査とも「社会環境の変化」が最も多く、商業施 設の環境変化への敏感な対応を伺うことができるが、今回調查の店 舗では「建物の存在自体」が最も多く、更に直接的理由となってく る。利用形態別の状況は、テナント用では前回・今回調査とも「社 会環境の変化」が最も多く、環境変化一の対応が求められる賃貸市 場の厳しさが推察される。

存続期間の各区分における、主要因の状況の詳細を、図 6 で示す。 存続期間 31 年以上のものについては、「老朽化陳腐化」は、前回調 査では長くなるほじ割合が大きくなるのに対し、今回調查では次第
に小さくなっている。「社会環境の変化」は、前回調査では存続期間 が長くなるほじ割合が小さくなり、今回調査では大きくなっている。 この状況は、「老朽化陳腐化」と「社会環境の変化」の関係が逆の傾 向となっていることを示している。次に「建物の存在自体」につい ては、前回調查では存続期間の最頻 21〜30 年に過半の回答数が集 中したが、今回調査では存続期間に関係なく回答数は分散している。 更に「建物の老朽化陳腐化に関寸る理由」が、建物の取壊しのき っかけになっているのかについて、他の主要因との関係を表 6 によ り確認寸る。即ち、取壊し理由の主要因における、「建物の老朽化陳 腐化に関する理由」が付随的要因である回答 (図 5 の点線部分) は、 前回・今回調查とも、他の項目が主要因となっている回答の概初過 半以上を占め、取壊される建物の多くが老朽化陳腐化を伴っている。 前回調查の「建物の存在自体」の老朽化陳腐化を伴う割合が低いの は、地価高騰で土地費に対する建築費の相対的な割安感が影響した ものと推察する。

表 7 建物諸元の各区分における、取壊し理由の主要因として最 も多く示されたものの状況

\begin{tabular}{|c|c|c|c|c|}
\hline 所在地 & 首都圏外 & 首都圏 (都心3区は除く) & 都心3区 & $\begin{array}{l}\text { 有効 } \\
\text { 回答 }\end{array}$ \\
\hline 2007 年 & 老朽化陳腐化(32\%) & 建物の存在自体(42\%) & 社会環境の変化(50\%) & 89 \\
\hline 1991年 & 敷地(27\%) & 老朽化陳腐化(32\%) & 社会環境の変化(39\%) & 154 \\
\hline 存続期間 & 短い(20年未満) & \begin{tabular}{|c|} 
最頻(2007:31 40年、1991 \\
年:21 30年)
\end{tabular} & 長い(51年以上) & \\
\hline 2007年 & 社会環境の変化(43\%) & 老朽化陳腐化(41\%) & 社会環境の変化(50\%) & 74 \\
\hline 1991年 & 社会環境の変化(32\%) & 社会環境の変化(34\%) & 老朽化陳腐化(40\%) & \begin{tabular}{|r|}
137 \\
\end{tabular} \\
\hline 構造種別 & $\mathrm{RC}$ 造 & SRC造 & S造 & $\begin{array}{l}\text { 他構造 } \\
\text { は除く }\end{array}$ \\
\hline 2007年 & 建物の存在自体 $(30 \%)$ & 社会環境の変化(41\%) & \begin{tabular}{|c|} 
建物の存在自体·社会 \\
環境の変化(各42\%)
\end{tabular} & 69 \\
\hline 1991年 & 社会環境の変化(31\%) & 老朽化陳腐化 $(29 \%)$ & 敷地(33\%) & 109 \\
\hline 延床面積 & $0 \sim 1000 \mathrm{~m}^{2}$ & $1000 \sim 3000 \mathrm{~m}^{2}$ & $3000 \mathrm{~m}^{2} \sim$ & \\
\hline \begin{tabular}{|l|} 
2007年 \\
1991 年 \\
\end{tabular} & $\begin{array}{l}\text { 建物の存在自体 }(58 \%) \\
\text { 社会環境の変化 }(25 \%) \\
\end{array}$ & $\begin{array}{l}\text { 老朽化陳腐化 }(38 \%) \\
\text { 老枋化陳腐化(35\%) }\end{array}$ & $\begin{array}{l}\text { 社会環境の変化 }(39 \%) \\
\text { 建物用途(39\%) } \\
\end{array}$ & $\begin{array}{r}76 \\
146 \\
\end{array}$ \\
\hline 建物用途 & オフィス & 店舗 & オフィス＋店舗 & $\begin{array}{l}\text { 他用途 } \\
\text { は除く }\end{array}$ \\
\hline 2007年 & 老朽化陳腐化(36\%) & 建物の存在自体 $(46 \%)$ & 社会環境の変化(60\%) & 60 \\
\hline 1991年 & 社会環境の変化(33\%) & 敷地·社会環境の変化(各30\%) & 社会環境の変化(38\%) & 82 \\
\hline 利用形態 & 自社用 & テナント用 & 共用 & \\
\hline 2007年 & 建物の存在自体 $(54 \%)$ & 社会環境の変化(39\%) & 老朽化陳腐化(58\%) & 79 \\
\hline 1991年 & 老朽化陳腐化(25\%) & 社会環境の変化(39\%) & 敷地(40\%) & 150 \\
\hline
\end{tabular}

存続期間 件数

\begin{tabular}{|c|c|c|c|}
\hline \multirow{2}{*}{$\begin{array}{r}0-20 \begin{array}{r}7 \text { 件 } \\
19 \text { 件 }\end{array} \\
\end{array}$} & 43 & 14 & \multirow{4}{*}{$\begin{array}{l}\square \text { 2.敷地 } \\
\text { 社会環堷 } の \text { 変化 }\end{array}$} \\
\hline & 26 & \begin{tabular}{|l|l|l|}
11 & 11 & 5 \\
\end{tabular} & \\
\hline \multirow{2}{*}{$\begin{array}{r}61-30 \text { 件 } \\
56 \text { 件 } \\
\end{array}$} & \multicolumn{2}{|c|}{33} & \\
\hline & 13 & 9 R & \\
\hline \multirow{2}{*}{$\begin{array}{r}31-40 \begin{array}{r}27 \text { 件 } \\
26 \text { 件 }\end{array} \\
\end{array}$} & \begin{tabular}{l|l}
4 & 19 \\
\end{tabular} & 11 & \multirow{4}{*}{$\begin{array}{l}\square 4 . \text { 建物用途 } \\
\square 5 . \text { 維持管理 } \\
\square 6 . \text { 老朽化陳腐化 } \\
\square 7 . \text { その他 }\end{array}$} \\
\hline & 27 & \begin{tabular}{|l|l|l|l|}
8 & 4 & 15 & 8 \\
\end{tabular} & \\
\hline \multirow[t]{2}{*}{ 24件 } & 21 & 21 & \\
\hline & 17 & 17 & \\
\hline \multirow{2}{*}{$\begin{array}{r}51-60 \quad 6 \text { 件 } \\
17 \text { 件 }\end{array}$} & 33 & 17 & \multirow{4}{*}{$\begin{array}{l}2007 \text { 年サンプル数 } 74 \\
1991 \text { 年サンプル数 } 137\end{array}$} \\
\hline & \begin{tabular}{|l|l|}
12 & 12 \\
\end{tabular} & 35 & \\
\hline \multirow{2}{*}{ 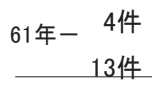 } & 25 & 75 & \\
\hline & \begin{tabular}{|l|l|}
8 & 15 \\
\end{tabular} & 23 & \\
\hline
\end{tabular}

図 6 存続期間別の取壊し理由（上 2007 年 下 1991 年） 
3-6. 取壊し理由の主要因と存続期間の対法定耐用年数比等の関係

今回調査において、建物の存続期間の対法定耐用年数比(以下「存 続期間／法定耐用年数」とする) と延床面積および取壊し理由の主要 因の関係について、図 7 に示寸。

図中のサンプル数が若干少なくなっているのは、竣工時期・延床 面積の記述なし、不明を除き、更に主要因サンプル数が 1 は除いた ためである。

全体的に【存続期間／法定耐用年数】の平均は 0.96 であるが、特 に延床面積が $1000 \mathrm{~m}^{2}$ 台以下では広くバラケている。「建物の存在自 体」は、延床面積が全体平均 $9408 \mathrm{~m}^{2}$ 以下であり、【存続期間／法定 耐用年数】の平均と関係なくバラケ、この結果は、規模が小さい建 物は使い道がなくならないよう可変性の取り入れが長寿命化に不可 欠であることを示唆していると考える。存続期間の最頻の $31 \sim 40$ 年で $41 \%$ （表 7）を占めた「建物の老朽化陳腐化」は、【存続期間 ／法定耐用年数】が平均值以下に分布していることから、必ずしも、 古いから、また建物の償却年数に達したから当該理由で取壊すので はなく、耐震補強・リニューアルを検討した結果、建替えを選択し ていることが推察できる。「社会環境の変化」は、【存続期間／法定 耐用年数】、延床面積とも広く分布し、特に当該理由は法定耐用年数 に関係なく、また存続期間の 20 年未満で $43 \%$ 、 51 年以上で $50 \%$ （表 7）を占めていることから、再開発等の社会環境の変化に対し て建物を社会資産として認識することが、存続期間の短い建物を少 なくし、また長く存続している建物を更に長命化させる上で不可欠 であることが分かる。
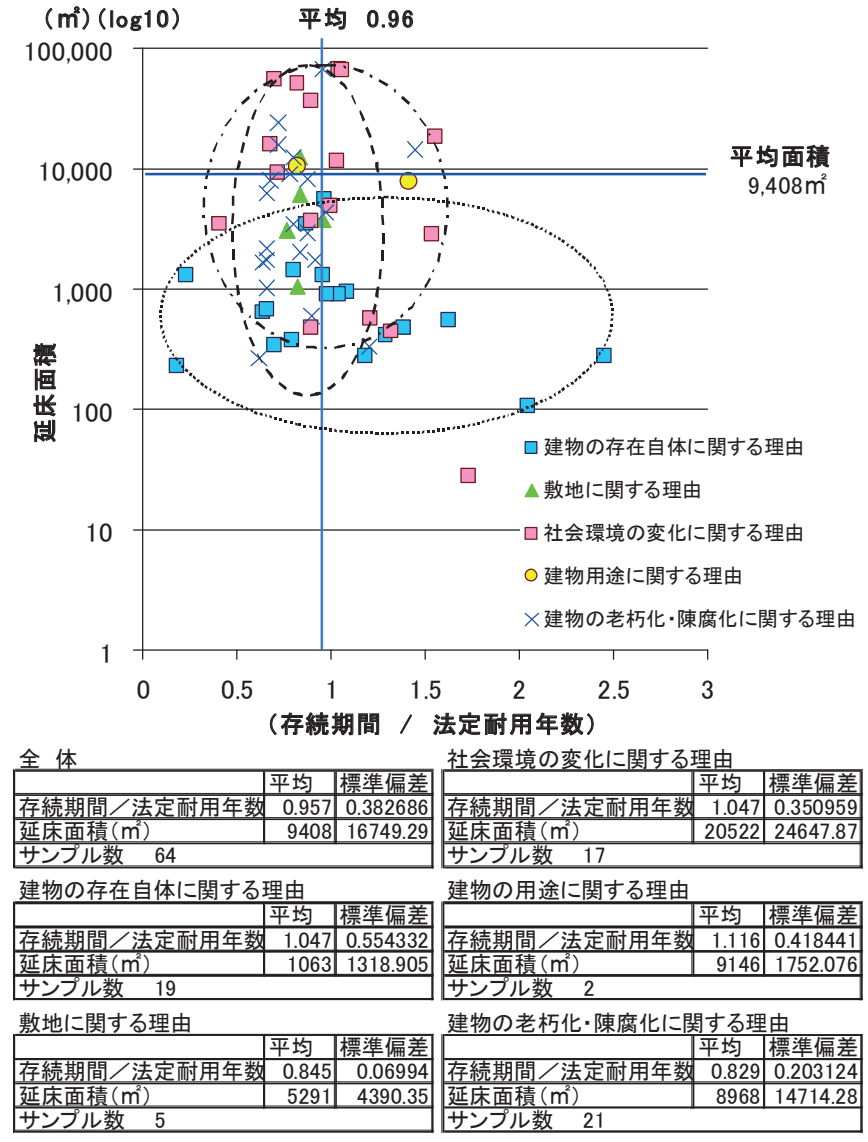

図 7 存続期間 /法定耐用年数および延床面積と主要因

\section{4.まとめ}

本研究の成果の主なものは、以下のとおりである。

(1)取壊し建物の存続期間の山は、地価高騰期の前回調査では竣工後 21 30 年で且つビル竣工の多い年次であった。地価安定期の今回調 查ではその山が、竣工後 30 年以上で且つビル竣工の多い年次であ り、前回調査と比心゙ 10 年の存続期間の延長が認められた。

(2)取り壊し建物之新築建物の延床面積の変化について、新旧建物の 面積区分でみると、前回調查では新築建物に区分を超えた面積の増 加が多かったが、今回調査では新旧建物の面積区分の同一が多かっ た。今回調査の取壊し建物の用途がオフィスに限ると、新旧の延床 面積が判明しているもののうち $1 / 3$ の延床面積が 1 割未満の増加 ないし減少であった。

(3)取壊し理由（小項目）は、主要因と付随的要因を合計した全体集 計が、今回調查では、前回調查で相対的には多くなかった資産運用 に係わる「建物の使い道がなくなった」・「維持管理費用が増加した」、 旧耐震基準に係わる「地震・強風に耐えられなくなった」が相対的 に多くなった。

(4)「建物の老朽化陳腐化に関する理由」(大項目) は、今回調查では、 存続期間の最頻 31〜 40 年で最も多く示された主要因であり、必ず しも、古いから、また建物の償却年数に達したから当該理由で取壊 すのではないことが推察でき、更に各主要因（当該要因を除く）の 付随的要因であることが多いこと分かった。特に、当該要因の小項 目である「建物の污れが目立つようになった」は、付随的要因では 最も多く建物取り壊しの有力なきっかけであることが推察できる。 (5)「社会環境の変化に関する理由」(大項目) は、今回調查では取壊 し建物の存続期間が 20 年未満の短い建物と 51 年以上の長い建物に 最も多く、社会環境の変化に対して建物を社会資産として認識する ことが長寿命化させる上で不可欠であることが分かる。

(6)「建物の存在自体」（大項目）は、今回調査では【存続期間／法定 耐用年数】がバラケ、規模が小さい建物は使い道がなくならないよ う可変性の取り入れが不可欠であることを示唆していると考える。

以上、これらのことは、建物の耐用性に関わる要因の一端を明ら かにし、原価性に基づく建物の資産価值評価上で、大いに参考にな るものと考えられる。なお、建物の取壊しの際、法定耐用年数を意 識しているかについては、【存続期間／法定耐用年数】等からは確認 できず、これについては今後、財務面からの法定耐用年数に対する 経営者の認識を調查 14 する必要がある。

調査に当たり、（社）日本ビルヂング協会連合会事務局の方々に は、多大なご協力を頂きましたことにつき、厚くお礼申し上げます。 今後は、さらに、建物の維持保全に関わる投資実態の調查を展開 し、原価性に基づく建物の資産価值評価に資する知見を蓄積してい きたい。

なお、本論文の一部は、2008 年 3 月関東支部学術講演発表》に加 筆修正したものである。

\section{参考文献}

1）漆崎昇ほか：産業連関表を利用した建築業の環境負荷推定、日本建築学 会計画系論文集、No.549、pp.75-82、2001.11

2) 環境省：産業廃棄物の排出及び処理状況等(平成 18 年度実績)について

3）鑑定評価理論研究会 (監修 建設省宅地政策課)：解説 不動産鑑定評価基 準、第 1 版、pp.247-248、pp.296-297、1970.5.5 
4）門脇惇: 不動産鑑定評価要説、9 訂版、pp.83-84、1983.4.20

5）江間博：不動産鑑定評価論詳解、pp.17-18、1993.10.1

6）吉田倬郎、小松幸夫、飯田恭一ほか：日本建築学会第 8 回建築生産管理 技術シンポジウム論文集 建物の取壊し理由に関する調査、pp.359-366、 1992

7）吉田倬郎、飯田恭一:建物の取壊し理由に関する調査一1991 年調査との比 較、日本建築学会関東支部 78 回研究報告集 II 、pp.209-212、2008.3

8）吉田倬郎、飯田恭一:木造借家の朽廃に関する判例の研究一社会的耐用性 の見地から朽廃の考察、日本建築学会大会学術講演梗概集 F-1 分冊 pp.1145-1146、2007.9

9）吉田倬郎、佐藤貴英：耐用性に優れた建物に関する調査・研究一ヒアリ ングと 2 件の事例調査の報告、日本建築学会大会学術講演梗概集 経済· 住宅分冊 pp.927-928、1994.9

10）吉田倬郎：耐用性からみた建築および設備の問題点一建物所有者の意識 調査に基づく考察、日本建築学会大会学術講演梗概集 建築経済・住宅問 題分冊 pp.1919-1920、1993.9

11）海野英晴：耐用性の概念、日本建築学会大会学術講演梗概集 計画系分 冊 pp.949-950、1991.9

12）（財）日本不動産研究所：全国オフィスビル調查 2009 年調査、2009.10

13）（財）日本不動産研究所：市街地価格指数、2009.5

14）円満隆平：地方民間企業の C R E 戦略実態調查、JAFM Current No.144 pp.14-17、2008.10

（2009年 7 月13日原稿受理，2010年 3 月11日採用決定） 